\title{
THE EFFECT OF GENOTYPE AND GROWING SEASONS ON YIELD AND QUALITY OF OATS ON PSEUDOGLEY SOIL
}

\author{
Vera Rajičić ${ }^{1}$, Dragan Terzić ${ }^{1}$, Vera Popović ${ }^{\star}$, Violeta Babić ${ }^{1}$, Dragoslav Đokić1, \\ Nenad Đurićs ${ }^{3}$, Snežana Branković ${ }^{4}$
}

\begin{abstract}
Oat is widely grown in Western Serbia and compared to other cereal crops is reputed to be better suited for production under marginal environments, including low fertility soils and cool wet climates. To determine the effect of cultivar and growing seasons on the yield and components of the oats yield two varieties were examined during three years, in the field experiment of the secondary agricultural-chemical school "Dr Đorđe Radić" in Kraljevo. Trials were arranged according to a randomized scheme in five replications. The following oat traits were analyzed: grain yield, 1000-kernel weight, test weight and plant height. The experiment was performed on extremely acidic pseudogley soil. The obtained results show a high effect of the years on grain yield and certain parameters of its quality. On average, the highest yield of oats $2.879 \mathrm{t} \mathrm{ha}^{-1}$ was obtained in the variety Vranac. The results of these studies indicate a significant impact of the growing season on grain yield and quality of oats, grown on poor soils of the pseudogley type, which is often present in Western Serbia. Grain yield shows a tendency to increase in years with a higher total amount and better distribution of precipitation during the critical stages of oat plant development.
\end{abstract}

Key words: Avena sativa L., grain yield, plant height, test weight

\section{Introduction}

Oat (Avena sativa L.) is a plant species that has significantly fewer fertilization requirements than other small grains. This plant species has a higher power of absorbing nutrients from soils that are not fit for the cultivation of wheat, such as acidic soils as well as other poor soils of marginal value (Jelić et al., 2013). In recent years, total production and areas under oats, both in the world (Dumlupinar et al., 2019) and in Serbia (Mandić et al. 2019; Rajičić et al., 2020), have been diminishing sharply. According to FAO (Faostat, 2020) based on the 10-year average (2009-2018), oats are sown annually on an area of about 9.73 million ha, with an average yield of $2.359 \mathrm{t} \mathrm{ha}^{-1}$. In Serbia, oats are grown on an area of 31.500 ha, with an average grain yield of $2.460 \mathrm{t} \mathrm{ha}^{-1}$.

In recent years, the demand for oats has been increasing, because of their dietary properties and biologically highly valuable nutrients contained in the grain. In addition to livestock nutrition, it is also useful and important in human nutrition. Due to the high quality of proteins with high solubility and digestibility (Mut et al., 2018), oat grains are used for the production of easily digestible products of high nutritional value in the food industry, such as oatmeal, flakes, grits, flour (Sterna et al., 2016; Ugrenović et al., 2021).

The amounts of applicable nitrogen, phosphorus and potassium nutrients depend on

\footnotetext{
Original Scientific Paper (Originalni naučni rad)

${ }^{1}$ Rajičić V, Terzić D, Babić V, Đokić D, University of Niš, Faculty of Agriculture, Kosančićeva 4, Kruševac, Serbia ${ }^{2}$ Popović V, Institute of Field and Vegetable Crops, Maksima Gorkog 30, Novi Sad, Serbia

${ }^{3}$ Đurić N, University of John Nezbit, Faculty of Biofarming, Backa Topola, Serbia

${ }^{4}$ Branković S, University of Kragujevac, Faculty of Science, Radoja Domanovića 12, Kragujevac, Serbia

*e-mail: vera.popovic@ifvens.ns.ac.rs ; drvvpopovic@gmail.com
} 
the resistance of the cultivated oat varieties to crop lodging and low temperatures, soil fertility, soil physical properties, agroecological conditions of the area, planned yield and economic power of the producer (Đekić et al., 2012; Krishna et al., 2014; Zielinski et al., 2017; Szatanik-Kloc et al., 2019). For high yields of oats, complex NPK fertilizers need to be used with the prolonged action of manure applied on the preceding crop (Jelic et al., 2013).

For most types of soil in our conditions (Serbia), to achieve high yield and good grain quality, on average, $60-90 \mathrm{~kg} \mathrm{ha}^{-1}$ of N, 60-90 kg ha-1 of $\mathrm{P}_{2} \mathrm{O}_{5}$ and $40-60 \mathrm{~kg} \mathrm{ha}^{-1}$ of $\mathrm{K}_{2} \mathrm{O}$ pure nutrients should be applied (Jelic et al., 2013). Jelić and Milivojević (2015) point out that phosphorus and potassium fertilizers are introduced in winter oats $50 \%$ in the basic tillage and $50 \%$ before sowing, while in spring oats all phosphorus and potassium quantities are introduced in autumn under basic tillage. In more humid regions, the amount of nitrogen for fertilization is added early in the spring during intense tillering (the first fertilization with half of the anticipated amount) and the second fertilization at the beginning of stem elongation with the remaining amount of nitrogen. In the case of spring oats in arid regions, the entire amount of nitrogen is given before basic treatment or pre-sowing preparation, i.e. without top dressing (Rajičić et al., 2020).

The aim of this study was the determination of the influence of semi-arid ecological environmental factors of Western Serbia on the spring oat varieties and its differences in stability and adaptability concerning the grain yield and parameters of grain quality.

\section{Material and methods}

\section{Plant materials and field trials}

Field experiments were performed on the experimental field of the secondary agricultural-chemical school "Dr Đorđe Radić" in Kraljevo $\left(43^{\circ} 43^{\prime} 00^{\prime \prime} \mathrm{N}, 20^{\circ} 40^{\prime} 60^{\prime \prime E}, 198 \mathrm{~m}\right.$ above sea level) during three growing seasons (2015, 2016 and 2017) in rain feed conditions, to analyze the yield and quality of oat grains poor soils of the pseudogley type, which is often present in Western Serbia.

The experiments were set up according to randomized block design, with a plot size of $500 \mathrm{~m}^{2}(25 \mathrm{~m} \times 20 \mathrm{~m})$ in five replications. Oats have been preceded by maize in all seasons. The sowing was performed within the optimum agrotechnical period (March 19, 2015, March 17,2016 , and March 21, 2017) at a $12.5 \mathrm{~cm}$ row spacing. NPK fertilizer formulation (15:15:15) was used in the experiment in pre-sowing soil preparation. The spring oat varieties Vranac and Lovćen originating from the Kragujevac Centre for Small Grains was selected as the material for the experiment. Fertilization was carried out in the 2-3 leaf stage, and nitrogen was applied in the form of ammonium nitrate (AN, 33\% N).

The following properties were analyzed: grain yield $\left(\mathrm{t} \mathrm{ha}^{-1}\right)$, 1000-kernel weight $(\mathrm{g})$, test weight $\left(\mathrm{kg} \mathrm{hl}^{-1}\right)$ and plant height. Grain yield was measured for each plot and converted to grain yield in tha-1 based on $14 \%$ grain moisture, after which a sample was taken for analysis of 1000 grain weight and test weight.

\section{Soil conditions}

The trial at the secondary agricultural-chemical school "Dr Đorđe Radić" in Kraljevo, Serbia, was performed on pseudogley soil characterized by unfavourable physical characteristics and poor water-air regime, with frequent water or air deficiencies. According to the results of agrochemical analysis, the soil is acidic ( $\mathrm{pH}$ in $\mathrm{H}_{2} \mathrm{O} 5.42$ and $\mathrm{pH}$ in $\mathrm{KCl} 4.46$ ), poor in humus $(2.19 \%)$, poor in available phosphorus ( $<10 \mathrm{mg} 100^{-1} \mathrm{~g}$ of soil) and medium provided with readily available potassium (13$18 \mathrm{mg} 100^{-1} \mathrm{~g}$ of soil).

\section{Meteorological conditions}

This study was conducted over three years period in Kraljevo, Serbia in the area which is located in the Čačak-Kraljevo valley and belongs to the Western Morava River region. It is surrounded by a large number of mountain ranges and their hills through which the wide river valleys of the West Morava, the lower Ibar 
and the lower Gruža intersect. The location of the trials was in a zone of temperate continental climate, with uneven distribution of precipitation by months. The data presented in Figure 1. for the oat growing season analyzed (2015-2017) suggest differences in weather conditions between the years of the study and the long-term mean for the region. The total amounts of rainfall were above the perennial average in the surveyed growing seasons (2015, 2016,2017 ), with a rather uneven monthly distribution. Weather conditions in the growing period in 2016 were marked by high rainfall during May, while rainfall in April was significantly lower. Variable and moderately warm weather, with less precipitation than average, marked June 2016 and 2017 (Figure 1).

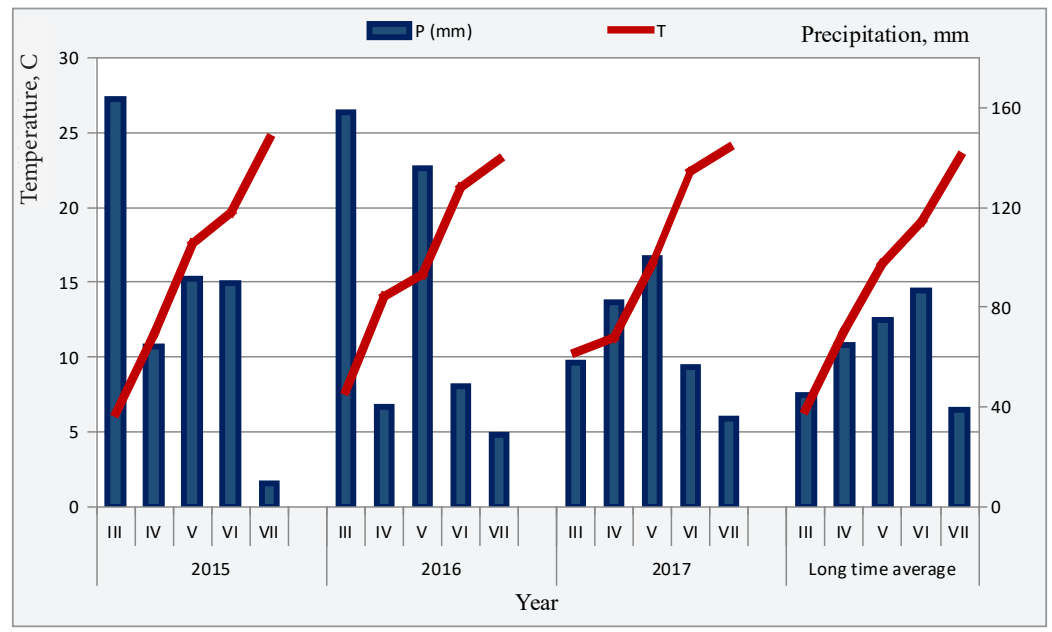

Figure 1. Precipitation $(\mathrm{mm})$ and average air temperature $\left({ }^{\circ} \mathrm{C}\right)$

during the microtrials, Kraljevo

Grafikon 1. Padavine ( $\mathrm{mm}$ ) i prosečna temperatura vazduha $\left({ }^{\circ} \mathrm{C}\right)$ tokom ispitivanja, Kraljevo

Temperature variations on average were higher in the third compared to the first and second seasons. During the experiment (20152017), the differences between the mean precipitation values and the perennial average in the first and second years of the study were the highest in March and May.

\section{Statistical Analysis}

Experimental data were analyzed by descriptive and analytical statistics using the statistics module Analyst Program GenStat (2013) for PC/Windows 7. Analysis of variance (ANOVA) and F-test were computed to determine the significance of different sources of variations (at $\mathrm{p} \leq 0.05$ and $\mathrm{p} \leq 0.01$ ). Relative dependence was defined through correlation analysis (Pearson's correlation coefficient), and the coefficients that were obtained were tested at the $5 \%$ and $1 \%$ levels of significance.

\section{Results and discussion}

\section{Grain yield and yield properties}

Average values of grain yield, 1000-kernel weight, test weight and plant height of investigated spring oat varieties are presented in Table 1.

The average grain yield of spring oats for the whole trial over the three-year study period was $2.823 \mathrm{t} \mathrm{ha}^{-1}$ (Table 1). The highest average yield was obtained by variety Vranac $(2.879 \mathrm{t}$ $\left.\mathrm{ha}^{-1}\right)$. The average grain yield of all varieties in 2015 was $2.695 \mathrm{t} \mathrm{ha}^{-1}$. In the second year of testing, the highest yield of all varieties was achieved (3.161 $\mathrm{t} \mathrm{ha}^{-1}$ ). In 2017 the average grain yield was $2.614 \mathrm{t} \mathrm{ha}^{-1}$ (Table 1 ).

Tested varieties achieved the highest average yield, 1000-kernel weight and test weight in 2016 and the lowest in 2017. A significant increase in yields and yield properties in the second year of testing compared to the first and third years was due to the favourable effect of environmental factors, i.e. temperature and precipitation, on the yield components. Com- 
pared to the perennial average, rainfall in the second year of testing was significantly higher in May, which, with favourable temperatures, led to the formation of more grains per panicle and thus to higher yields. A significant deviation of precipitation and temperature from the perennial average in the Republic of Serbia is becoming more pronounced (Đekić et al., 2012; Terzić et al., 2018). Namely, the total rainfall is reflected on a perennial average but the distribution, especially in the critical stages of development, is significantly disrupted (Đekić et al., 2018; Terzić et al., 2019; Rajičić et al., 2020). By analyzing the results obtained, we can conclude that there is a significant dependence on grain yield and the year of study, which is in agreement with the results of Jelic et al. (2013). In the studies performed by Rajičić et al. (2020), the authors state that the yield and grain yield components of spring oats vary significantly depending on the nitrogen doses used, variety and conditions of the year, as well as their complex interactions.
The 1000-kernel weight average for all the varieties was the highest in 2016 (30.31 g), slightly lower in 2015 (29.29 g) and the lowest in 2017 (27.92 g). The average three-year value was $29.17 \mathrm{~g}$ (Table 1). The tested cultivars differed in terms of 1000-kernel weight. For all years on average, the highest 1000-kernel weight had the variety $\operatorname{Vranac}(29.38 \mathrm{~g})$. A growing period in 2017 at the time of grain loading was noticeable by drought and high temperatures, which reduced the 1000-kernel weight. Obtained values were slightly higher than the mass of 1000 grains found by Jelic et al. (2013) and Kaziu et al. (2019) and lower than the results obtained by Đekić et al. (2018), Tomple and Hwan (2018), Dumlupinar et al. (2019) and Rajičić et al. (2020).

The average test weight of spring oats for the whole trial over the three-year study period was $43.56 \mathrm{~kg} \mathrm{hl}^{-1}$, and it was significantly higher in $2016\left(46.64 \mathrm{~kg} \mathrm{hl}^{-1}\right)$ compared to $2017\left(40.85 \mathrm{~kg} \mathrm{hl}^{-1}\right)$. For all years on average, the highest test weight had the variety Vranac $\left(43.97 \mathrm{~kg} \mathrm{hl}^{-1}\right)$. The values obtained were slight-

Table 1. Average values of investigated traits of spring oats

Tabela 1. Prosečne vrednosti ispitivanih osobina kod jarog ovsa

\begin{tabular}{|c|c|c|c|c|c|c|c|c|}
\hline \multirow{2}{*}{ Varieties } & \multicolumn{2}{|c|}{2015} & \multicolumn{2}{|c|}{2016} & \multicolumn{2}{|c|}{2017} & \multicolumn{2}{|c|}{ Average } \\
\hline & $\bar{x}$ & $\mathbf{S}$ & $\bar{x}$ & $\mathbf{S}$ & $\bar{x}$ & $\mathbf{S}$ & $\bar{x}$ & $\mathrm{~S}$ \\
\hline \multicolumn{9}{|c|}{ Grain yield (t ha-1) } \\
\hline Vranac & 2.718 & 0.450 & 3.294 & 0.373 & 2.624 & 0.353 & 2.879 & 0.476 \\
\hline Lovćen & 2.671 & 0.198 & 3.029 & 0.391 & 2.604 & 0.368 & 2.768 & 0.362 \\
\hline Average & 2.695 & 0.329 & 3.161 & 0.387 & 2.614 & 0.340 & 2.823 & 0.420 \\
\hline \multicolumn{9}{|c|}{ 1000-kernel weight (g) } \\
\hline Vranac & 29.56 & 0.805 & 30.56 & 0.313 & 28.02 & 0.680 & 29.38 & 1.231 \\
\hline Lovćen & 29.02 & 0.370 & 30.06 & 0.650 & 27.82 & 0.934 & 28.97 & 1.143 \\
\hline Average & 29.29 & 0.656 & 30.31 & 0.549 & 27.92 & 0.777 & 29.17 & 1.186 \\
\hline \multicolumn{9}{|c|}{ Test weight $\left(\mathrm{kg} \mathrm{hl}^{-1}\right)$} \\
\hline Vranac & 43.36 & 1.199 & 47.48 & 1.027 & 41.06 & 2.193 & 43.97 & 3.105 \\
\hline Lovćen & 43.03 & 1.708 & 45.80 & 0.897 & 40.64 & 0.696 & 43.16 & 2.442 \\
\hline Average & 43.19 & 1.402 & 46.64 & 1.269 & 40.85 & 1.550 & 43.56 & 2.776 \\
\hline \multicolumn{9}{|c|}{ Plant height (cm) } \\
\hline Vranac & 112.9 & 6.128 & 118.6 & 5.683 & 109.6 & 4.615 & 113.7 & 6.391 \\
\hline Lovćen & 111.0 & 8.775 & 116.6 & 5.030 & 106.2 & 7.918 & 111.3 & 8.154 \\
\hline Average & 111.9 & 7.205 & 117.6 & 5.168 & 107.9 & 6.367 & 112.5 & 7.304 \\
\hline
\end{tabular}


ly lower than the hectolitre weight obtained by Jelic et al. (2013) and Đekić et al. (2018).

The highest plant height of tested varieties was in $2016(117.6 \mathrm{~cm})$, slightly lower in 2015 $(111.9 \mathrm{~cm})$ and the lowest in $2017(107.9 \mathrm{~cm})$, with an average of $112.5 \mathrm{~cm}$. During the threeyear study, the highest height of oat plants was found in the variety Vranac. More favourable conditions in 2016 caused higher average plant height compared to 2015 and 2017. Batalova et al. (2010) point out the significant influence of the variety on the height of oat plants, which ranged from $102.4 \mathrm{~cm}$ to $133.5 \mathrm{~cm}$.

\section{Analysis of variance between observed traits of oats}

The influence of year and genotype, alongside their interaction on the yield, 1000-kernel weight, test weight and plant height of spring oats, during three growing years are shown in Table 2.
Based on the analysis of variance, we can conclude that the influence of growing seasons on grain yield was highly significant $\left(F_{\exp }=7.014^{* *}\right)$, while the influence of different varieties on yield was non-significant $\left(\mathrm{F}_{\exp }=0.512\right)$.

Analysis of variance has found highly significant effect of growing seasons on the yield $\left(\mathrm{F}_{\exp }=7.014^{* *}\right)$, the 1000-kernel weight $\left(\mathrm{F}_{\exp }=32.322^{* *}\right)$, test weight $\left(\mathrm{F}_{\exp }=42.566^{*}\right)$ and plant height $\left(\mathrm{F}_{\text {exp }}=5.975^{* *}\right)$. These results are in agreement with the outcome of Jelic et al. (2013) and Rajičić et al. (2020). Different varieties did not significantly affect the yield and yield properties. Based on the analysis of variance, it can be concluded that the interactions of the growing season and the varieties were also non-significant for all investigated traits $(p>0.05)$.

Table 2. ANOVA values of traits of investigated oat varieties

Tabela 2. ANOVA vrednosti ispitivanih osobina kod sorti ovsa

Effect of the year on the analyzed traits

\begin{tabular}{lcccc}
\hline \multicolumn{1}{c}{ Traits } & $\begin{array}{c}\text { Mean sqr } \\
\text { Effect }\end{array}$ & $\begin{array}{c}\text { Mean sqr } \\
\text { Error }\end{array}$ & F (2, 27) & p-level \\
\hline Grain yield $\left(\mathrm{t} \mathrm{ha}^{-1}\right)$ & 0.873 & 0.124 & $7.014^{* *}$ & 0.003 \\
1000-kernel weight $(\mathrm{g})$ & 14.382 & 0.445 & $32.322^{\star *}$ & 0.000 \\
Test weight $\left(\mathrm{kg} \mathrm{hl}^{-1}\right)$ & 84.819 & 1.993 & $42.566^{\star *}$ & 0.000 \\
Plant height $(\mathrm{cm})$ & 237.358 & 39.723 & $5.975^{\star *}$ & 0.007 \\
\hline
\end{tabular}

Effect of cultivar on the analyzed traits

\begin{tabular}{lcccc}
\hline \multicolumn{1}{c}{ Traits } & $\begin{array}{c}\text { Mean sqr } \\
\text { Effect }\end{array}$ & $\begin{array}{c}\text { Mean sqr } \\
\text { Error }\end{array}$ & F (1, 28) & p-level \\
\hline Grain yield $\left(\mathrm{t} \mathrm{ha}^{-1}\right)$ & 0.092 & 0.179 & $0.512 \mathrm{~ns}$ & 0.480 \\
1000-kernel weight $(\mathrm{g})$ & 1.281 & 1.411 & $0.908 \mathrm{~ns}$ & 0.349 \\
Test weight $\left(\mathrm{kg} \mathrm{hl}^{-1}\right)$ & 4.921 & 7.804 & $0.631 \mathrm{~ns}$ & 0.434 \\
Plant height $(\mathrm{cm})$ & 44.408 & 53.673 & $0.827 \mathrm{~ns}$ & 0.371 \\
\hline
\end{tabular}

Effect of the year by cultivar interaction

\begin{tabular}{lcccc}
\hline \multicolumn{1}{c}{ Traits } & $\begin{array}{c}\text { Mean sqr } \\
\text { Effect }\end{array}$ & $\begin{array}{c}\text { Mean sqr } \\
\text { Error }\end{array}$ & F (2, 24) & p-level \\
\hline Grain yield $\left(\mathrm{t} \mathrm{ha}^{-1}\right)$ & 0.045 & 0.132 & $0.340 \mathrm{~ns}$ & 0.715 \\
1000-kernel weight $(\mathrm{g})$ & 0.086 & 0.440 & $0.196 \mathrm{~ns}$ & 0.823 \\
Test weight $\left(\mathrm{kg} \mathrm{hl}^{-1}\right)$ & 1.424 & 1.918 & $0.743 \mathrm{~ns}$ & 0.486 \\
Plant height $(\mathrm{cm})$ & 1.758 & 42.692 & $0.041 \mathrm{~ns}$ & 0.960 \\
\hline
\end{tabular}

${ }^{\mathrm{ns}}$ non significant; ${ }^{*}$ significant at $0.05 ;{ }^{* *}$ significant at 0.01 
Grain yield of spring oats is greatly influenced by the fertilization system, which is one of the key factors, which affects the yield and its quality (Khan et al., 2014; Monjezi-Zadeh et al., 2018), but it needs to be aligned with climate and soil conditions as well as the requirements of the variety (Tomple and Hwan, 2018; Dumlupinar et al., 2019; Rajičić et al., 2020). In Western Serbia, very significant differences between the 1000 grain weight and the year of research have been found by Jelic et al. (2013) and Rajičić et al. (2020), while highly significant differences in the conditions of the Šumadija region have been found by Đekić et al. (2018). A significant influence of the growing season on test weight in oats is also established by Jelić et al. (2013) and Rajičić et al. (2020).
A significant influence of year and genotype on the height of oat plants is obtained by Mut et al. (2018) and Dumlupinar et al. (2019).

\section{Correlation analysis of the studied oat traits}

Correlation coefficients based on all traits tested during 2015-2017 had positive values (Table 3). Over a three-year study period (2015-2017), highly significant positive correlation coefficients were found between yields and 1000 -kernel weight $\left(\mathrm{r}=0.511^{* *}\right)$ and test weight $\left(r=0.466^{* *}\right)$, then between the 1000-kernel weight and test weight $\left(r=0.785^{* *}\right)$ and between the test weight and the plant height $\left(\mathrm{r}=0.534^{* *}\right)$. Also, significant positive correlations were found between 1000-kernel weight and plant height $\left(\mathrm{r}=0.411^{*}\right)$.

Table 3. Correlations between the analyzed traits

Tabela 3. Korelacije izmedu analiziranih osobina

\begin{tabular}{|c|c|c|c|c|}
\hline Traits & Grain yield & 1000-kernel weight & Test weight & Plant height \\
\hline \multicolumn{5}{|c|}{$2015-2017$} \\
\hline Grain yield & 1.00 & $0.511^{* *}$ & $0.466^{* *}$ & 0.205 \\
\hline 1000-kernel weight & & 1.00 & $0.785^{* *}$ & $0.411^{*}$ \\
\hline Test weight & & & 1.00 & $0.534^{* *}$ \\
\hline Plant height & & & & 1.00 \\
\hline
\end{tabular}

*significant at $0.05 ;{ }^{* *}$ significant at 0.01

A strong positive correlation between small yields and 1000-kernel weight has been found by many researchers (Krishna et al., 2014; Terzic et al., 2018), medium (Jelic et al., 2013; Đekić et al., 2014, Güngör et al., 2017), while weak positive dependence has been identified by Vaisi and Golparvar, (2013) and Rajičić et al. (2020). Positive correlations between yields and test weight have been found by Đekić et al. (2014), Terzic et al. (2018) and Rajičić et al. (2020). Negative and significant dependencies of 1000-kernel weight and test weight have been found by Đekić et al. (2014), Terzic et al. (2018) and Rajičić et al. (2020).

\section{Conclusion}

Grain yield and quality were the best in the 2016 growing season, due to the favourable rainfall distribution, which favourably affected the production of oats, while the worst quality was established in 2017. The highest average three-year yield of oats was found in the variety Vranac (2.879 $\left.\mathrm{t} \mathrm{ha}^{-1}\right)$. The impact of climatic factors on the yield components and quality of oat grains was highly significant. Highly significant positive correlation coefficients between yields with 1000-kernel weight and test weight were found over a three-year study period.

\section{Acknowledgements}

The authors sincerely thank the secondary agricultural-chemical school "PhD Đorđe 
Radić" in Kraljevo, Serbia, which has performed the experiment. This paper is part of the projects, Grant numbers: 451-03-9/2021$14 / 200383$ and 200032, financed by the Ministry of Education, Science and Technology Development of Republic of Serbia, and FAO Project „Redesigning the exploitation of small grains genetic resources towards increased sustainability of grain-value chain and improved farmers' livelihoods in Serbia and Bulgaria“-GRAINEFIT, 2020-2023, PR-166Serbia; and Bilateral Project Republic of Serbia and Montenegro, 2019-2021: „Alternative cereals and oil crops as a source of healthcare food and important raw material for the production of biofuel“.

\section{References}

Batalova GA, Changzhong R, Rusakova II, Krotova NV (2010): Breeding of naked oats. Russian Agricultural Science, 36: 93-5.

Đekić V, Staletić M, Milivojević J, Popović V, Jelić M (2012): Nutritive value and yield of oat grain (Avena sativa L.). Agroznanje, 13(2): 217-224.

Đekić V, Milovanović M, Popović V, Milivojević J, Staletić M, Jelić M, Perišić V (2014): Effects of fertilization on yield and grain quality in winter triticale. Romanian Agricultural Research, 31: 175-183.

Đekić V, Jelić M, Popović V, Terzić D, Đurić N, Grčak D, Grčak M (2018): Parameters of grain yield and quality of spring oats. Proceedings of the Journal of PKB Agroekonomik Institute, 24(1-2): 81-86.

Dumlupinar Z, Güngör H, Dokuyucu T, Herek S, Tekin A, Akkaya A (2019): Agronomical Screening of OGLE1040/TAM O-301 Oat Genetic Mapping Population. Sains Malaysiana, 48 (5): 975-981.

FAO (2020): Available online: http://faostat. fao.org

GENstat Release 16.2 (PC/Windows 7) (2013): GenStat Procedure Library. Release PL24.2. VSN International Ltd. Rothamsted, UK.

Güngör H, Dokuyucu T, Dumlupinar Z, Akkaya A (2017): Yulafta (Avena spp.) Tane Verimi ile Bazı Tarımsal Özellikler
Arasındaki İlişkilerin Korelasyon ve Path Analizleriyle Saptanması. Tekirdağ Ziraat Fakültesi Dergisi, 14(1): 61-68.

Jelic M, Dugalić G, Milivojević J, Đekić V (2013): Effect of liming and fertilization on yield and quality of oat (Avena sativa L.) on an acid luvisol soil. Romanian Agricultural Research, 30: 249-258.

Jelic M, Milivojevic J (2015): Gvožđe, mangan, cink i aluminijum u kiselim zemljištima Centralne Srbije. Monografija /Iron, manganese, zinc and aluminium at acid soils of Central Serbia. Monograph, University of Priština, Faculty of Agriculture, Lešak, Serbia.

Kaziu I, Kashta F, Celami A (2019): Estimation of Grain Yield, Grain Components and Correlations between Them in some Oat Cultivars. Albanian Journal of Agricultural Sciences, 18(1):13-19.

Khan A, Anjum MH, Rehman MKU, Zaman Q, Ullah R (2014): Comparative study on quantitative and qualitative characters of different oat (Avena sativa L.) genotypes under agro-climatic conditions of Sargodha, Pakistan. American Journal of Plant Sciences, 5: 3097-3103.

Krishna A, Ahmed S, Pandey HC, Kumar V (2014): Correlation, Path and Diversity Analysis of Oat (Avena sativa L.) Genotypes for Grain and Fodder Yield. Journal of Plant Science \& Research, 2: 1-9.

Mandić D, Pržulj N, Đurašinović G, Jovović Z (2019): Productivity of facultative genotypes of oat in autumn and spring sowing. Selekcija i semenarstvo, 25(1): 1-8.

Monjezi-Zadeh M, Roshanfekr H, Hassibi P, Sorkhi B (2018): Evaluation Effect of Macro and Micro Nutritional Elements on Quantitative and Qualitative Characteristics of Oat Crop (Avena sativa L.). Journal of Crop Nutrition Science, 4(1): 33-46.

Mut Z, Akay H, Köse O (2018): Grain yield, quality traits and grain yield stability of local oat cultivars. Journal of Soil Science and Plant Nutrition, 18(1): 269-281.

Rajičić V, Popović V, Terzić D, Grčak D, Dugalić $\mathrm{M}$, Mihailović A, Grčak M, Ugrenović V (2020): Impact of Lime and NPK Fer- 
tilizers on Yield and Quality of Oats on Pseudogley Soil and their valorisation. Notulae Botanicae Horti Agrobotanici Cluj-Napoca, 48(4): 2134-2152.

Sterna V, Zute S, Brunava L (2016): Oat Grain Composition and its Nutrition Benefice. Agriculture and Agricultural Science Procedia, 8: 252-256.

Szatanik-Kloc A, Ambrożewicz-Nita A, Franus W, Józefaciuk G (2019): Early effect of clinoptilolite on yield and quality of oat (Avena sativa L.). Int. Agrophys., 33: 107112.

Terzić D, Đekić V, Jevtić S, Popović V, Jevtić A, Mijajlović J, Jevtić A (2018): Effect of longterm fertilization on grain yield and yield components in winter triticale.The Journal of Animal and Plant Sciences, 28(3): 830836.

Terzić D, Popović V, Malić N, Ikanović J, Rajičić V, Simić D, Lončarević V (2019): Effects of long-term fertilization on yield of side rates and organic matter content of soil in the process of recultivation. The Journal of Animal and Plant Sciences, 29(3): 790-795.
Tomple BM, Hwan JI (2018): Enhancing Seed Productivity and Feed Value of Oats ( $A v$ ena sativa L.) with Different Seeding Rate and Nitrogen Fertilizing Levels in Gyeongbuk Area. Journal of Agriculture \& Life Science, 52(6): 61-72.

Ugrenović V, Popović V, Ugrinović M, Filipović $\mathrm{V}$, Mačkić $\mathrm{K}$, Ljubičić $\mathrm{N}$, Popović $\mathrm{S}$, Lakić Ž (2021): Black Oat (Avena strigosa Schreb.) Ontogenesis and Agronomic Performance in Organic Cropping System and Pannonian Environments. Agriculture, 11 (1): 55 .

Vaisi H, Golparvar AR (2013): Determination of the best indirect selection criteria to improve grain yield and seed weight in oat (Avena sativa L.) genotypes. International Journal of Farming and Allied Sciences, 2: 747-50.

Zielinski A, Mos M, Wójtowicz T (2017): In vivo evaluation of vigor in naked and husked oat cultivars under drought stress conditions. Chilean Journal of Agricultural Research, 77 (2): 110-117. 


\title{
UTICAJ GENOTIPA I VEGETACIONE SEZONE NA PRINOS I KVALITET OVSA NA ZEMLJIŠTU TIPA PSEUDOGLEJ
}

\author{
Vera Rajičić, Dragan Terzić, Vera Popović, Violeta Babić, Dragoslav Đokić, \\ Nenad Đurić, Snežana Branković
}

\begin{abstract}
Sažetak
U cilju utvrđivanja uticaja sorte i vegetacione sezone na prinos i komponente prinosa ovsa ispitivane su dve sorte ovsa tokom tri vegetacione sezone na oglednom polju srednje poljoprivredno-hemijske škole “dr Đorđe Radić” u Kraljevu. Ogledi su postavljeni po šemi slučajnog rasporeda u pet ponavljanja. Analizirani su: prinos zrna, masa $1000 \mathrm{zrna}$, hektolitarska masa i visina biljaka. Ogled je zasnovan na ekstremno kiselom zemljištu tipa pseudoglej. Dobijeni rezultati pokazuju visok efekat vegetacione sezone na prinos zrna i određene parametre njegovog kvaliteta. U proseku, za sve sorte, tokom trogodišnjeg ogleda, najveći prinos ovsa 2.879 t ha $^{-1}$ dobijen je kod sorte Vranac. Rezultati ovih istraživanja ukazuju na značajan uticaj vegetacione sezone na prinos zrna i kvalitet ovsa gajenog na siromašnim zemljištima tipa pseudoglej koje je često zastupljeno na područiju Zapadne Srbije. Prinos zrna pokazuje tendenciju rasta u godinama sa većom ukupnom količinom i boljom raspodelom padavina tokom kritičnih faza razvoja biljaka ovsa.
\end{abstract}

Ključne reči: Avena Sativa L., hektolitarska masa, prinos zrna, visina biljke

Primljen: 05.05.2021. Prihvaćen: 27.06.2021. 